\title{
Academic Writing in the Caribbean: Searching for an Identity
}

\author{
Vivette Milson-Whyte \\ (iD) 0000-0003-1083-4693 \\ University of the West Indies, Mona
}

Dr. Vivette Milson-Whyte gave this speech as part of the 15th Annual Anatol Rodgers Memorial Lecture Series in February 2021. The speakers were invited to give the lecture due to the fact that their edited collection Creole Composition: Academic Writing and Rhetoric in the Anglophone Caribbean received the 36th Mina P. Shaughnessy Prize from the Modern Language Association of America.

\section{Introduction}

I am deeply honoured to have been invited to share in this lecture that is used annually to mark Mrs. Rodgers' contributions to the development of Bahamian society. Like the current Vice-President of the United States of America whose father is Jamaican, Mrs. Rodgers was a history maker. While we await the post-election accomplishments of VicePresident Kamala Harris, especially as they might resonate with the Caribbean, we know that in the audience are testaments to Mrs. Rodgers's achievements. As the first female Bahamian principal of the then Government High School, Mrs. Rodgers helped to nurture and ensure the academic and social development of significant numbers of Bahamian adolescents. Many of you in the audience this evening are familiar with those politicians and other professionals who would have won places to Government High School and who continue to contribute to the development of the Bahamian chain of islands and, by extension, the Caribbean region — and beyond.

As an educator, Mrs. Rodgers would have been interested in the research and writing of individuals like Dr. Oenbring and I. Along with Dr. Brianne Jaquette and the contributors of individual chapters in Creole Composition: Academic Writing and Rhetoric in the Anglophone Caribbean, we have produced a "first of its kind in the region"- a book "suggesting frameworks around which to build and further institutionalize and professionalize writing studies in the region." Through this book, we have contributed to a conversation about the academic writing education of students in postsecondary institutions in the Caribbean and of students of Caribbean origin in other places such as the United States of America. And, as you have heard, with this book, the Caribbean marks another first in terms of its selection for the Modern Language Association of America's award of the 36th Mina P. Shaughnessy Prize. Mina Shaughnessy, a widely respected teacher/scholar of writing studies and Mrs. Anatol Rodgers, a great Bahamian educator, make for good company. Out of the confluence of the manifestations of solid contributions to education and the development of human resources that we speak of this evening, I would like us to 
understand that we are still on a quest to chart Caribbean identity - to self-define-in terms of academic writing or advanced written literacy.

In an era of increasing access to higher education by previously excluded segments in each Caribbean country, the collection, Creole Composition, presents important work being done in The Bahamas and across the Caribbean to provide a sense of the identity of the students, instructors, and our body of work. Important as all of these contributions are, however, as the book says, "the collection is but 'part of the start' of discussions on what would constitute effective praxis regarding Anglophone Caribbean students' academic writing development" (p. 343). Indeed, there is still much research to be done regarding the development of Caribbean students' academic literacies, and I will be sharing with us why we need to continue the conversation - to expand the literature; in short, why we need to establish, through research, the mythos and ethos of teaching academic writing in the Caribbean context.

\section{Digging Deep}

To do this, I turn to the late Rex Nettleford. In Inward Stretch, Outward Reach: A Voice from the Caribbean, noted Caribbean scholar — and dancer — Rex Nettleford (1995) wrote that those who can see a brighter future after experiences of pain, suffering, and oppression demonstrate "survival" that "is a function of a people's capacity for inward stretch and outward reach-the cause, occasion and result of a certain life-tension that is potentially creative even while it threatens to be destructively disintegrative" (p. vi). He encouraged Caribbean peoples to go beyond survival, writing that "if much of the past was endured on the basis of inward stretch, the future must expand on this, extending and sustaining ideal, form and purpose for the region by outward reach" (p. xiv). I am borrowing Nettleford's image this evening - stretching inward, reaching outward as imperatives for facilitators of students' academic writing development in postsecondary institutions and for facilitators of language and literacy development at the secondary level in the Anglophone Caribbean. And I will reference the contributors to the book Creole Composition.

We need to dig deep and reach out for various reasons, and I'll be sharing just four of these this evening: The first is to present accurate profiles of our students. Who are the students who people our academic writing programmes in The Bahamas and elsewhere in the Caribbean? Let's use, as example, the case of Jamaica.

Figure 1

Graphical representation of Creoleinfluenced speakers.

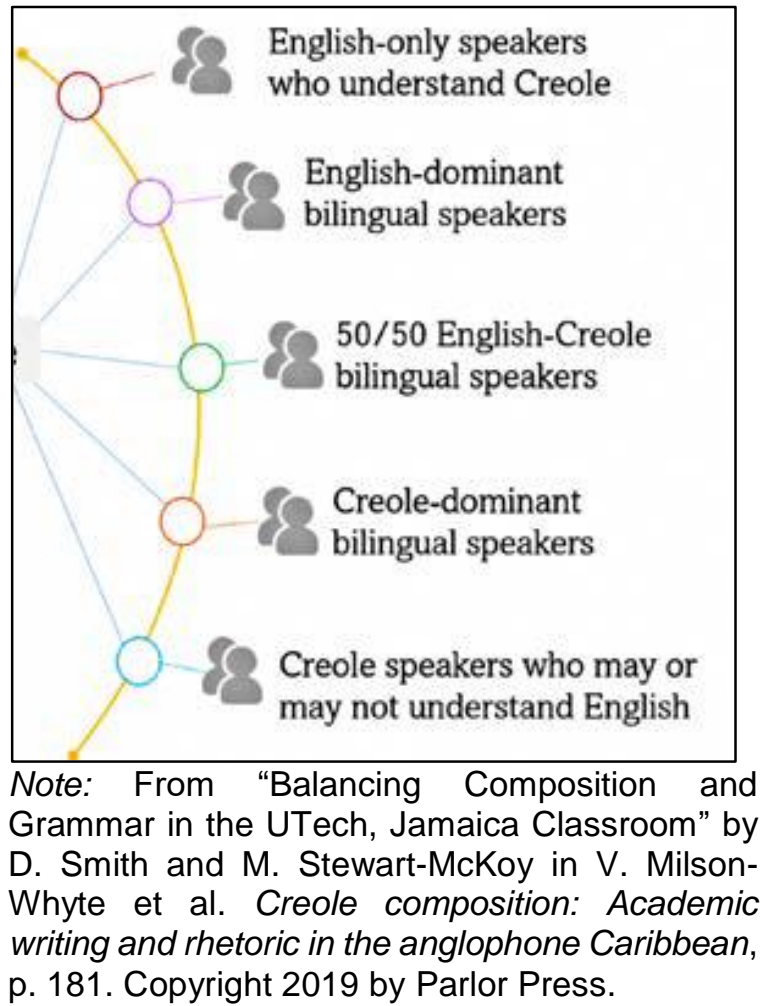


In my 2015 book, Academic Writing Instruction for Creole-Influenced Students, I indicate that to an outsider

Jamaicans' linguistic behaviours can appear enigmatic. Some Jamaicans are English-only speakers who understand Creole; some are English-dominant bilinguals; some are Creole-dominant bilinguals; some may be equally bilingual in Creole and English; some are Creoleonly speakers who may or may not understand English; some slide between the shifting poles in ways yet to be named; some do not acknowledge their linguistic profiles and behaviours, but all encounter Jamaican Creole. Since all Jamaicans are influenced in one way or another by the Creole, but are not all Creole-speaking, I refer to Jamaican students as Creoleinfluenced students." (Milson-Whyte, 2015, p. 6)

And by Creole, I am referring to what is called Patois in Jamaica but that linguists refer to as Jamaican Creole - one of the several English-lexified creoles in the Caribbean. The description of the situation in Jamaica might seem fairly easy to comprehend, I hope, but when we turn to The Bahamas with English and Bahamian Creole (also called Bahamian dialect, Bahamianese, dialect and so on), we must then consider segments of the population for whom French or Haitian Creole is significant. And I will allow us to imagine the diversity that could manifest in English composition (and other) classes at University of The Bahamas - even if students attempt/manage to conceal aspects of their linguistic repertoires by the time they reach the university.

In Mrs. Rodgers' time, entry into Government High School by ordinary Bahamians who were not of the white mercantile class was based on excellent performance in primary level examinations.
The meritocratic system that obtained then would have led to a kind of linguistic homogeneity in classrooms because the brightest and best in just about any system would also have mastered the language of instruction and been readied to surmount challenges attending advanced written literacy. With increasing possibilities for movement (through both legal migration and illegal travel) and the democratization of education that prevails today in many parts of the globe, there are significant expansions in cohorts and attendant increasing linguistic diversity in classrooms.

But what are Caribbean students like beyond their linguistic profiles or even their peculiar engagements with time (like arriving on "island time" for classes and leaving early as experienced by Shanti Bruce, an American professor who, in a 2015 publication, reflected on flying into The Bahamas to teach classes over 2-day periods for Nova Southeastern University)? What do we know about the transition from high school/secondary level to university in The Bahamas and the rest of the Caribbean? How prepared are students for the academic writing instruction they will receive in postsecondary contexts? What is the link between the Bahamas General Certificate of Secondary Education (the BGCSE) or other local or regional examination results and students' academic writing performance in postsecondary institutions like University of The Bahamas?

Annual results of Bahamian examinations may present a grim picture of students' writing at the secondary level. And we do have a few studies that tell us of weaknesses in other Caribbean students' writing, but we need follow-up studies to plumb students' challenges. Which aspects of academic writing do Bahamian students, for example, find most challenging? Which genres of writing present most difficulty for which 
groups of Caribbean students?

In Creole Composition, we see that Melissa Alleyne, of the Open Campus of The University of the West Indies located in Barbados, has begun to examine how Caribbean students' feelings and attitudes affect academic writing performance, and Christine Kozikowski from University of The Bahamas has examined how culture (concerning attitudes to time) can affect how much is accomplished in a teaching session, so another question is "What body of knowledge do we have to enable us to make comparisons between the attitudes and academic writing of differing cohorts of students in and from the Anglophone Caribbean?"

In general, we need statistics to engage with stakeholders as we make claims for our teaching and request changes to support certain students' academic writing development based on the profiles of them that we are presenting.

The second reason I am suggesting we should be digging deep is to show that we are doing more than teaching - and more than teaching English grammar. Teaching pedagogies are informed by theory, by research. Where is our body of writing reflecting the teaching pedagogies to which we subscribe, reflecting the research paradigms that inform our investigations into advanced written literacy in the Caribbean? What are our waves of writing and why did we experience such shifts? When did we, if we did, shift from a heavy English grammar emphasis to engage with, for example, process approaches to writing? Why are changes made when they are made in academic writing education and with what results in Caribbean postsecondary institutions?

Contributors Beverley Josephs and Clover Jones McKenzie as well as Daidrah Smith and Michelle Stewart-McKoy have started to contemplate pedagogical changes in one university in Jamaica, but we have to work our research muscles a little more. Have we been engaging with "Writing about writing" as proposed by Douglas Downs and Elizabeth Wardle in the United States? What is our take on transfer of learning? This is a sensitive, controversial subject (as Kathleen Yancey and her colleagues reminded in 2019). But what do we know about transfer of knowledge and skills from academic writing courses to other courses in Caribbean institutions? Does it happen? How? To what extent? Why do professors/lecturers in other courses sometimes contact an academic writing facilitator to ask "Did this/that student really pass the English Composition/academic writing course that you teach?"

What is our connection to new research into language (things like codemeshing, translingualism)? Codemeshing involves blending elements of different languages to create meaning in writing and translingualism involves negotiating in and across languages in specific instances of communication instead of relying on predefined rules to determine meaningthings we do daily in speech in the Caribbean, that some of us do not think should be done in formal settings, but that scholars elsewhere are attempting to formalize.

What we might call the language question in the supposedly English-speaking Caribbean is unsettled because of uncertainties regarding English and the English Creoles as well as internal and intra-regional migration that has led to not insignificant representations of other languages and varieties in some of our countries. These developments require a posture-like that of contributor Kendra Mitchell- of coming to terms with the diversity in our academic writing classrooms. What's the result likely 
to be if we engage with the suggestion of contributor Heather M. Robinson to take a truly postcolonial perspective in our teaching of academic writing? This approach involves allowing students to, as she says, "incorporate a plural, postcolonial subject position into what they write, so as to bring together the many facets of the linguistic identities which, in a colonial space, are often split, by force" (p. 321). Contemplation of scholarship regarding treatment of linguistic diversity in the teaching of writing elsewhere might help us in the Caribbean to address issues of language in ways that would minimise the linguistic trauma many students have experienced in Caribbean educational systems - and that Carmeneta Jones and Jacob Dyer Spiegel describe in Creole Composition.

Of course, we have a huge challenge that traverses the various educational levels in that many different strategies and areas of focus are conflated: language, English, writing, writing in a first language, writing in a second language - all different entities and elements, all of which are of relevance to the Caribbean often, unfortunately, get lumped as English and teaching gets reduced to teaching English grammar.

However, I am suggesting that where there is still heavy emphasis on teaching "English grammar", can we also focus our concerns on style perhaps seeing it as "culturally structured intuition" as proposed by Keith Rhodes in 2019 (and he's an American lawyer and scholar of writing)? If we join the inquiry into style, we can help to determine if - as Rhodes proposes_- "style flows from the writer's intuitive intentions more than from any other influence-including any specific methods that we teach" (p. 242).

Because of our region's linguistic and other experiences, we have much to contribute to academic conversations about language. We can also contribute to conversations about transnational composition. We have been engaging in this for decades in the Caribbean-think of The University of the West Indies starting as the University College of the West Indies, a college of the University of London or think off-shore universities. What have we to say about them and advanced written literacy instruction for Caribbean students? Shanti Bruce has given the perspective from the North American end, but what is ours? What is the experience like in the Caribbean where Caribbean institutions set up franchises in other countries in the region with arrangements for local facilitators to teach their academic writing courses? Or what's the experience with satellites of University of The Bahamas that are set up away from Nassau?

Whatever we engage with in our various institutions across the region, it is our research that can and will show to what end we engage and with what levels of success. And it is through dissemination of our research findings that we will be able to contribute to the broader field of writing studies.

The third reason is that research about academic writing in the Anglophone Caribbean could lead to better articulation of writing in individual countries and across the region. What are similarities and differences in teaching and assessing writing in the various postsecondary institutions in any one Caribbean country, across universities and other postsecondary institutions?

Contributors Annife Campbell as well as Daidrah Smith and Michelle Stewart-McKoy have started to address issues related to assessment of writing in their various institutions in Jamaica. In other publications, Dr. Oenbring and his colleagues have been sharing their research regarding academic writing in The Bahamas. But how do their 
findings compare to occurrences elsewhere? What's the situation in other institutions in these and other islands? We need studies to help to show that our assessment of writing is consistent and grounded in theories of assessment, in the local context, and so on.

And with regard to teacher response to student writing specifically, what are our response modes? How do students respond to teacher/tutor feedback? How do we know that our labouring in grading and providing other forms of feedback on student papers is worth the effort? What's the impact of the digital age on our on teaching, on how we teach revision of writing, on our response to student writing, or on assessing writing?

In 2020, the regional examining body, the Caribbean Examinations Council (CXC), like other institutions in the region, had to make some adjustments to its assessment procedures. As some of us can recall, that body had to field many questions from representatives of Ministries of Education in multiple countries as teachers and students were concerned about some of the results released in Summer 2020. CXC even responded to some requests by doing a review of the 2020 assessment, with some papers being re-marked. As many of you know, in The Bahamas, there were challenges attending proctoring the BGCSE in 2020. And few students and parents were happy when the results of the examinations were disseminated.

Of course, these developments indicate the very serious issue of how prepared we are to respond to emergencies - to alter writing assignments and assessments at short notice and when we know that situations like a pandemic can magnify already existing inequities (see Brabazon, 2020). Whether in normal or new-normal times, we need research results to support a solid record of excellent teaching and valid and reliable assessment within and across Caribbean institutions and countries.

The fourth and final reason I'll share is that digging deep can contribute to professionalizing our work. Admittedly, researching about students' academic writing in the Anglophone Caribbean can mean painful inward stretching because of what Creole Composition presents as "grim descriptions of the material conditions" (Milson-Whyte et al, 2019, p. 349). But we need research addressing labour and working conditions too.

What does it mean to teach academic (and professional) literacies in The Bahamas? In the various English-speaking Caribbean institutional contexts? What are the joys and pains of the labour? How are the academic writing programmes in the Caribbean staffed? And what is the situation regarding contingent faculty? Is there any impact on outcomes? Are Writing Centres/Resource rooms a feature of Caribbean postsecondary academic writing programs?

Where are our guides for first year writing that would show what we value in writing? While guides for writing courses are available in some institutions, such as University of The Bahamas, in others there is reliance on external texts. This kind of outward reaching could be augmented by some inward stretching. And responses to the questions above could propel our programmes forward-as well as augment the discipline of Writing Studies.

\section{What Types of Studies are Needed?}

Various kinds of studies seem necessary. We need longitudinal studies_-slow research, but we also need some fast action research. Perhaps needed are colleagues who will engage in and/or support studies involving both big data and little data. We are yet to 
know what exactly are the connections between reading and writing in the Anglophone Caribbean where many students do not develop literacy in their first language which is often an English-lexified Creole. What's the situation for students of Haitian Creole background in The Bahamas who hop across more languages or language varieties to get to the Bahamian English language or composition classroom? In such instances in which Creole-influenced students do not develop biliteracy and cognitive development is necessarily truncated, how do we facilitate students' development of critical thinking - itself dependent on cognitive maturity? Are the methods effective? And how do we test students' critical thinking skills?

So far, in the Anglophone Caribbean, governments have not been convinced to engage in mother-tongue education or in bilingual/biliterate programmes at the primary level despite statements from the United Nations (United Nations Educational, Scientific and Cultural Organization, 1953) and from linguists emphasising the value of developing literacy in one's first language. Perhaps we need a longitudinal study regarding what's been happening in Haiti and Curaçao in those areas in which elementary level instruction occurs in Haitian Creole and in Papiamentu, respectively, and how students in those projects fare at the postsecondary level.

In 2019-2020, a Bilingual-Biliterate Intervention Project was conducted at The University of the West Indies, Mona. It involved teaching writing laboratory sessions in Jamaican Creole and English in one semester of a year-long writing course for students who do not qualify for the regular first-year academic writing courses. Students wrote out their thoughts in Jamaican Creole (or however the thoughts arose) and then, with the tutor's assistance, converted these to
English. Students wrote in eye-dialect Creole because there was insufficient time to teach them the Cassidy-Le Page orthography and simultaneous with meeting course deadlines. The principal investigator, Shyrel-Ann Dean, is still in the process of analysing the data but has indicated some interesting preliminary findings:

- Students wrote powerful, heartfelt, almost tear-jerking reflections about how safe and comfortable they felt because of the opportunities afforded them to speak and write in a language in which they were comfortable.

- Students felt they had learnt a lot, with one in science and technology reporting that one of his professors had commented on the notable - positive - change in his writing.

- Students felt the teaching approach would be valuable for other students and asked why it was not used earlier in their schooling (Shyrel-Ann Dean, personal communication, February 3, 2021).

Of course, we anticipate the full findings from this study and hope that they will help with achieving better outcomes for students, especially those most removed from the kinds of reading and writing demanded in university studies but for whom the need to address the affective domain may be most critical.

I am also suggesting in terms of studies we need that consideration be given to how we may engage more with classical rhetorical notions? Dr. Oenbring has suggested seeing each of the islands of the Caribbean archipelago as a Greek polis (that is, a political entity ruled by its body of citizens than by one identified ruler/monarch) and Kevin Browne, a former speaker in this lecture series, has presented the Caribbean carnivalesque through a rhetorical lens. Browne (2013) has written, "the Caribbean 
carnivalesque, as an exemplary practice, has the potential for activating consciousness among historically dispossessed people, thus enabling the desires of individuals to take form through collective practice" (p. 11).

Their work is but a start indicating how, if we contemplate rhetorical notions a little more and appreciate Caribbean selfhood a little more, we may privilege regional practices such as our penchant for orality and collective celebrations and give a voice to those more marginalized than others in Caribbean space (as contributor Jacob Dyer Spiegel tried to do in his teaching of academic writing in The Bahamas).

\section{How to Proceed with Research}

\section{Creole Composition indicates}

Our suggestion is that colleagues inside and outside the Caribbean pattern Hamilton in Miranda's ... musical and "write everything down"-document reflections, plumb teaching situations, investigate new and old practices/strategies - as a way not only to claim and ascribe agency in Caribbean national contexts but also to continue to participate in broadening international discussions regarding rhetoric and composition/writing studies. (MilsonWhyte et al., 2019, p. 345)

Although Caribbean societies are largely oral, as writing researcher Charles Bazerman (2008) asserts, "it is by writing that we inscribe our place in the literate world and all the social systems that depend on literacy" ( $p$. 1). Our inscriptions in the Caribbean can help the newcomer, as Dr Oenbring was in 2009, to see beyond the shame, stigma, avoidance and rigour that are usually immediately apparent regarding language and the teaching of writing in the Caribbean.
Creole Composition also acknowledges that

the kind of consistent engagement with research that we envision is no small order ... teaching loads are heavy in Caribbean institutions, and course or program coordinators do not get adequate release time for the demands of course or program administration." (Milson-Whyte et al., 2019, p. 345)

Despite these challenges, I am suggesting research will help with professionalizing and with the recognition of writing program administration work as scholarship in the Caribbean. One might say research and professional organization is a chicken and egg situation. However, we need a body of scholarly work in Writing Studies to bolster any professional organization of the kinds suggested by Valerie Combie and Clover Jones McKenzie and Tresecka CampbellDawes in the collection.

Calling on scholarship on writing program administration in light of empirical evidence for the work course and programme leaders do in our sphere could see changes in administrators' and colleagues' understanding of our labours-labours as outlined by Tyrone Ali and other contributors to Creole Composition. With the rapid proliferation of information in our globalised knowledge economies, and with anecdotal evidence that students read and write in peculiar ways in this millennium, there is urgency with which research into academic writing in the Caribbean needs to grow - and it might serve us well to make connections with our colleagues engaged in students' academic writing development or development of what they call university literacies in the Spanish and French-speaking Caribbean.

Establishing such connections means we should proceed with a caution from Antonio 
Benítez-Rojo (1996) who has learned from the efforts of multiple Caribbean theorists that

every intellectual venture directed toward investigating Caribbeanness is to become an unending search. It doesn't matter where you've left from, it doesn't matter where you've gone, it doesn't matter which ideology you profess, Caribbeanness will always remain beyond the horizon. (p. xi)

Nettleford (1995), however, has reminded us in the face of this elusive Caribbeannes that: "In typical Caribbean fashion, dialectical impulses are upon us and the hope-in-despair that informs our day-to-day living is probably our way of asserting some kind of faith in [the] future" (p. 185).

In my attempt to plumb what Nettleford (1995) presented as creative tension in Caribbean experiences, I have spent some time digging into our archives, reading other attempts at documenting our work in teaching composition/academic writing in the Caribbean simultaneous with intervening in conversations in the United States regarding language. And Dr. Oenbring has been contributing to augmenting the scholarship on postsecondary writing instruction in the Caribbean. As I pointed out gaps that remain, I trust you saw them as areas needing investigation-that you are seeing that our region is teeming with opportunities for research regarding written literacy. Continuing research is dependent on many variables. One of these is funding. I trust that the award of what is dubbed "the Shaughnessy" by American academics in composition to a book with significant contribution from professors at University of The Bahamas and various other universities in the Caribbean will be encouragement for potential donors. In a word, everyone can purchase Creole Composition via the Parlor Press site, Amazon.com and other reputable online book merchants so that publishers will want to continue to publish research from the Caribbean. But to get publishable materials, at University of The Bahamas and in other Caribbean universities, we certainly need the support of alumni and other potential donors-individuals like Mrs. Rodgers's offspring - to help us to continue researching.

Ultimately, then, operating in spaces in the Caribbean where, as Derek Walcott (1979) said, "The Sea is History" and Kamau Braithwaite (1974) said "The Unity is Submarine," I encourage us to dance academically, to keep stretching, reaching inward, outward - to deepen and expand our engagements in researching, theorising about and teaching academic writing in the Caribbean - to students of Caribbean origin, so that, like Mrs. Anatol Rodgers, we may make positive contributions in The Bahamas and elsewhere in the Caribbean; specifically for us, we may bring a Caribbean sensibility to Writing Studies by foregrounding what may be uniquely Caribbean with regard to academic writing. 


\section{References}

Bazerman, C. (2008). Introduction. In C. Bazerman (Ed.), Handbook of research on writing: History, society, school, individual, text (pp. 1-4). Lawrence Erlbaum Associates.

Benítez-Rojo, A. (1996). The repeating island: The Caribbean and the postmodern perspective. (J. Maraniss, Trans.). Duke University Press.

Brabazon, H. (2020). The academy's neoliberal response to COVID-19: Why faculty should be wary and how we can push back. Academic Matters: OCUFA's Journal of Higher Education.

http://academicmatters.ca/neoliberalresponse-to-covid-19/.

Braithwaite, E. K. (1974). Contradictory Omens: Cultural diversity and integration in the Caribbean. Savacou Publications.

Bruce, S. (2015). So close, yet so far: Administering a writing program with a Bahamian campus. In D. Martins (Ed.), Transnational writing program Administration (pp. 130-150). Utah State UP.

Downs, D. \& Wardle, E. (2007). Teaching about writing, righting misconceptions: (re)envisioning 'first-year composition' as 'introduction to writing studies.' College Composition and Communication, 58(4), 552-584. https://www.jstor.org/stable/20456966
United Nations Educational, Scientific and Cultural Organization. (1953). The use of vernacular languages in education. http://www.inarels.com/resources/unes co1953.pdf

Milson-Whyte, V. (2015). Academic writing instruction for creoleinfluenced students. University of the West Indies Press.

Milson-Whyte, V., Oenbring, R., \& Jaquette, B. (Eds.). (2019). Creole composition: Academic writing and rhetoric in the anglophone Caribbean. Parlor Press.

Nettleford, R. (1995). Inward stretch, outward reach: A voice from the Caribbean. Caribbean Diaspora Press.

Rhodes, K. (2019). Feeling it: Toward style as culturally structured intuition. College Composition and Communication, 71(2), 241-267. https://digitalcommons.unl.edu/english facpubs/237/

Walcott, D. (1979). The star apple kingdom. Farrar, Strauss \& Giroux.

Yancey, K. B., Davis, M., Robertson, L. Taczak, K., \& Workman, E. (2019). The teaching for transfer curriculum: The role of concurrent transfer and inside- and outside-school contexts in supporting students' writing development. College Composition and Communication, 71(2), 268-295. https://www.proquest.com/docview/23 50468446?pqorigsite $=$ gscholar $\&$ fromopenview $=$ true 